\title{
THE ROLES OF KNOWLEDGE SHARING IN MEDIATING THE EFFECT OF SELF-EFFICACY AND SELF-LEADERSHIP TOWARD INNOVATIVE BEHAVIOR
}

\author{
Anak Agung Dwi Widyani ${ }^{1 *}$, I Wayan Gede Sarmawa², I Gusti Ayu Manuati Dewi ${ }^{3}$ \\ ${ }^{1}$ Mahasaraswati University, Denpasar, Indonesia \\ ${ }^{2}$ Warmadewa University, Denpasar, Indonesia \\ ${ }^{3}$ Udayana University, Bali, Indonesia \\ *Corresponding autor; Email: dwiwidyani@yahoo.com
}

\begin{abstract}
This research is to investigate the correlation between self-efficacy, self-leadership, and knowledge sharing as observed in the innovative behavior of Endek weaving small enterprise in Bali. Innovation is an interesting issue in SMEs, due to its sustainability efforts of the business. Endek weaving is one unique product that has social and economic value. The unit of analysis is Endek weaving small enterprise in Klungkung, a regency located in the east area of Bali, as it is the center production of Endek weaving in Bali area. The number of respondents is 96 employees of Endek weaving companies in Klungkung Regency. Data analysis method in this research is using the quantitative approach with the tool of Structure Equation Model Partial Least Square (SEM PLS). The results show that self-efficacy and self-leadership have significant influences to knowledge sharing. Self-efficacy has an insignificant influence on innovative behavior, while self-leadership has a significant influence on innovative behavior. Knowledge sharing has a significant influence on innovative behavior. An important finding of this research is knowledge sharing as a mediator of self-efficacy to innovative behavior.
\end{abstract}

Keywords: Self-efficacy, self-leadership, knowledge sharing, innovative behavior.

\section{Introduction}

Small and Medium Business, often called Small Medium Enterprise (SME), has an important influence on the economic growth of a country (Oduntan, 2014). This is reinforced by Madanchian, Hussein and Noordin (2015) that SMEs contribute to stimulating economic growth as well as overcoming the crisis in Malaysia. In addition, the existence of SMEs is able to encourage development of economic growth and innovation. According to Karadag (2016), SMEs have the advantages of being able to survive in conditions of economic crisis because it has characteristics and utilizes local resources in this business activities. Another role of small and medium businesses is to provide employment to the business world, as well as to increase state revenues (Tasan, 2013; Hsiao, Brouns, Bruggen and Sloep, 2012).

Despite of having a central role in the economy of a country, SMEs still do not provide significant added value, because the existing human resource innovation capability in SMEs is still relatively low (Yonica, 2013). In the era of a highly dynamic business world, it requires innovative behavior in order to survive and develop business (Omri, 2015). According to Tasan (2013), rapid changes and high levels of environmental uncertainty require innovative skills to achieve growth and sustainability of SMEs. Companies with innovative resources will be able to increase production and market share (Begonja, Cicek, Balboni, \& Gerbin 2016). Innovation becomes a vital need for companies which is affected by several factors, including self-efficacy (Hsiao, Brouns, Bruggen, \& Sloep 2012; Widyani, 2016), self-leadership (Omar \& Mahmud, 2014; Widyani, Sugianingrat, \& Sarmawa, 2016; Carmeli, 2006), and knowledge sharing (Lin, 2007; Yu, Fang, \& Chieh, 2013; Ofori, Osei, Mensah, Affum, 2015; Widyani, 2016). Therefore, this study examines the influence of self-efficacy, self-leadership and knowledge sharing on the innovative behavior of employees of Endek weaving company in Klungkung. Klungkung Regency is chosen as the object of research because Klungkung Regency is the center of Endek craftsmanship in Bali.

\section{Self-Efficacy}

Self-efficacy is one's confidence in his ability to provide knowledge that is valuable to others, as stated by Shaari, Rahman and Rajab (2014), and Momeni, Ebrahimpour and Ajirloo (2014). In several studies, self-efficacy is the self-evaluation and confidence on personal skills and capabilities to respond to questions posted by other members, and to provide knowledge 
that is valuable and useful to others. Through sharing useful knowledge, people feel more confident in activities (Bandura, 1982), (Bandura, 1986). Self-efficacy is a form of self-evaluation that influences the decisions about what behaviors to undertake, the amount of effort and persistence to put forth when faced with obstacles, and finally, the mastery of the behavior (Igbaria \& Iivari, 1995). Generally, the perceived self-efficacy plays an important position in influencing individuals' motivation and behavior. However, the results of Park, Moon and Hyun (2014) show that self-efficacy does not have an effect on the results of work because employees with high selfesteem tend to be over confident and tend to always have a sense of satisfaction that ignores innovative behavior in dynamic environment.

\section{Self-Leadership}

Self-leadership is a combination of self-regulation, self-control, and self-management theories, which is then divided into three categories: behavior focus strategies, natural reward strategies, and constructive thought patterns strategies (Manz and Neck, 2004). According to Manz (1986) self-leadership is a process by which a person makes decisions based on his capacity and ability. Although individuals are motivated to complete tasks, but not everyone is capable of displaying innovative behavior; especially in the absence of self-navigation which is a key element in the concept of self-leadership (Hsiao, Brouns, Bruggen, \& Sloep 2012).

Self-leadership is a process in which employees motivate and direct themselves to achieve the desired behavior (Kor, 2016). According to Oduntan (2014), self-leadership and job tasks have a positive relationship. Self-leadership refers to a reflective internal process, which an individual consciously and constructively moves the mind and intentions towards the creation of desired change, improvement and innovative behavior (Carmeli, Weisberg \& Meiter 2006).

\section{Knowledge sharing}

A basic concept of knowledge management is that knowledge can be shared (Nonaka \& Takeuchi, 1995). Knowledge sharing can create a maximum opportunity of the organization ability, and to meet those needs and generate solutions and efficiencies that provide a business with competitive advantage (Olowodunoye, 2015).In the modern organization, knowledge sharing is an important process that can result in shared intellectual capitals, an increasingly important resource. Only when individual and group knowledge are translated into organizational knowledge, the organization can begin to manage this re- source effectively (Hoof \& Weenen, 2004). According Van Den Hooff and De Ridder (2004), knowledge sharing has two facets; collecting and donating knowledge. They define the donating knowledge as communication based upon an individual's own wish to transfer intellectual capital, and the collecting knowledge as an attempt to persuade others to share what they know. According to Alhady, Idris, Sawal and Azmi (2011), knowledge sharing behavior consists of two categories, knowledge collecting and knowledge donating, that communicate closely with each other in order to tap into the respondent's knowledge sharing behavior status. A number of studies have demonstrated that knowledge sharing is essential because it enables to enhance innovation (Abdallah, Khalil \& Divine, 2012). Thus to evaluate this premise, this research is an attempt to investigate the influence of knowledge sharing on innovative behavior.

\section{Innovative Behavior}

According to Scumpeter (1934), as the first scientist who can describe innovation, there are five types of innovation, which are:

1) New product introduction or qualitative change of existing product,

2) Process innovation new to an industry,

3) Opening of a new market,

4) Development of new sources of supply of raw materials or other inputs,

5) Changes in industrial organization (Changes in industrial organization).

The company is now required to be able to create new thinking and ideas, then offer innovative products as well as improved customer satisfactory service. According to Crossan and Apaydin (2010), innovation is the production or adoption, assimilation and exploitation that add value, renewal, and expansion of products, services, and the establishment of new systems. Innovation measurement comes into two forms, namely product innovation and process innovation (Hilmi, Faiz, Ramayah, \& Mustapha, 2011). The term innovation is defined as a breakthrough associated with new products. Jimenez, Daniel and Raquel (2011) define innovation as a broader concept that addresses product implementation, process innovation, and managerial innovation.

\section{Research Method}

The population of this research is Endek weaving employees in Klungkung regency which are about 2000 people spread over 55 weaving companies. Based on the Slovin formula, the number of research samples is 96 employees. The sample of respondents is done randomly. Each variable has 
several indicators. Self-efficacy variable consists of 6 indicators, self-leadership consists of 9 indicators, knowledge sharing consists of 6 indicators, and innovative behavior consists of 7 indicators. All items in each indicator are measured with a five Likert scale (1 $=$ strongly disagree, $5=$ strongly agree). Data analysis in this study is conducted using structural equation modeling (SEM) of partial least square (PLS) with smart PSL 3.0. The research model is as follows:

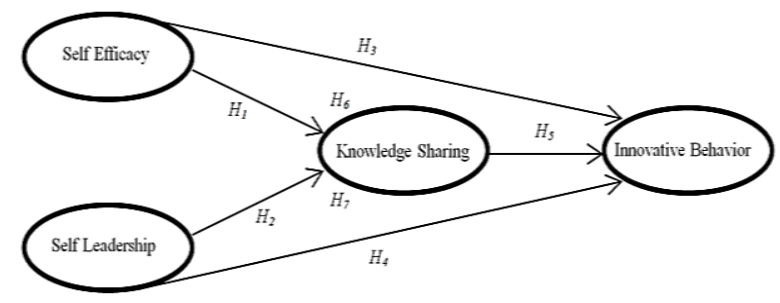

Figure 1. Research Model

\section{Result and Discussion}

The results of data analysis indicate that all indicators of research variable measurement consisting of self-efficacy, self-leadership, knowledge sharing, and innovative behavior are valid. It is shown through the outer loading coefficient which ranges from 0.557 to 0.915 , seen from the coefficient of Cronbach alpha as equal to 0.829-0.914, and observed from the composite reliability which shows values equal to $0.875-0.930$. Based on these results, the indicators and research variables can be said to be valid and reliable. The determinant coefficient $\left(R^{2}\right)$ is shown in Table 1.

\section{Table1}

Determination Coefficients $\left(\boldsymbol{R}^{2}\right)$

\begin{tabular}{lc}
\hline Dependent Variable & $\boldsymbol{R}^{2}$ Coefficient \\
\hline Knowledge Sharing & 0.572 \\
Innovative Behavior & 0.664 \\
\hline
\end{tabular}

Based on Table 1, it can be explained that the determination coefficient value of self-efficacy and self-leadership to knowledge sharing is 0.572 . This illustrates that $57.2 \%$ of knowledge sharing is influenced by self-efficacy and self-leadership, the rest is another factor outside the research model. While, $66.4 \%$ innovative behavior is influenced by selfefficacy, self-leadership, and knowledge sharing, the rest $(33.6 \%)$ is another factor outside the research model.

The fit model in this research is using the $Q$ Square Predictive Relevance $\left(Q^{2}\right)$, with a formula as follows:

$$
\begin{aligned}
Q^{2} & =1-\left[\left(1 \mathrm{R}^{2} \mathrm{Y} 1\right)\left(1 \mathrm{R}^{2} \mathrm{Y} 2\right)\right] \\
& =1-[(1-0.572)(0.664)]
\end{aligned}
$$

$$
\begin{aligned}
& =1-[(0.428)(0.336)] \\
& =1-[0.1438] \\
& =0.8562
\end{aligned}
$$

The result of $Q^{2}$ shows that the fit model is quite strong, where $85.62 \%$ relation between self- efficacy, self-leadership, and knowledge sharing variables toward innovative behavior variable can be explained by this research model.

Data processing with the Smart PLS 3.0 program, resulting in Figure 2.

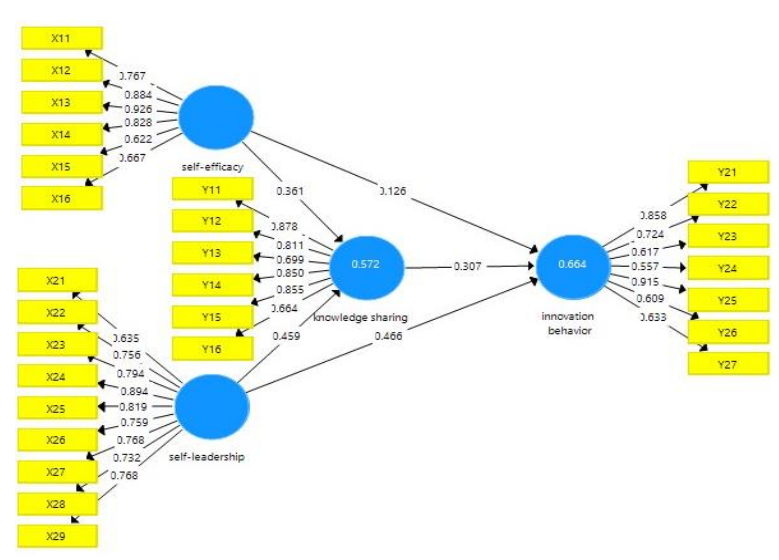

Figure 2. Effect of Self-Efficacy, Self-Leadership, Knowledge Sharing, on Innovative Behavior

Furthermore, the results of data analysis are presented in tabular form as shown in Table 2 which shows the direct and indirect effects between the independent variables to the dependent variable.

Table 2

Direct and Indirect Effect Self-Efficacy, Self-Leadership, Knowledge Sharing, to Innovative Behavior

\begin{tabular}{lccc}
\hline $\begin{array}{l}\text { Direct and Indirect } \\
\text { Effect }\end{array}$ & $\begin{array}{c}\text { Total } \\
\text { Effect }\end{array}$ & $p$-value & Information \\
\hline $\begin{array}{l}\text { Self-Efficacy } \rightarrow \text { Know- } \\
\text { ledge Sharing }\end{array}$ & 0.361 & 0.003 & significant \\
$\begin{array}{l}\text { Self-Leadership } \rightarrow \text { Know- } \\
\text { ledge Sharing } \\
\text { Self-Efficacy } \rightarrow \text { Innova- } \\
\text { tive Behavior }\end{array}$ & 0.459 & 0.000 & significant \\
$\begin{array}{l}\text { Sel-Leadership } \rightarrow \text { Innova- } \\
\text { tive Behavior }\end{array}$ & 0.466 & 0.000 & $\begin{array}{l}\text { significant } \\
\text { significant }\end{array}$ \\
$\begin{array}{l}\text { Knowledge Sharing } \rightarrow \\
\text { Innovative Behavior }\end{array}$ & 0.307 & 0.002 & significant \\
$\begin{array}{l}\text { Self-Efficacy } \rightarrow \text { Know- } \\
\text { ledge Sharing } \rightarrow \text { Innova- } \\
\text { tive Behavior }\end{array}$ & 0.111 & 0.013 & significant \\
$\begin{array}{l}\text { Sel-Leadership } \rightarrow \text { Know- } \\
\text { ledge Sharing } \rightarrow \text { Innova- } \\
\text { tive Behavior }\end{array}$ & 0.141 & 0.027 & significant \\
\hline
\end{tabular}


Based on Table 2, it can be explained as follows:

1. The direct influence of self-efficacy on innovative behavior is shown through the path coefficient of 0.126 with $p$-value of $0.213>0.05$. This means that self-efficacy has no significant effect on innovative behavior. The results of this study are contradictory to a number of previous research results, as performed by Momeni, Ebrahimpour and Ajirloo (2014); Hsiao, Chang, Tu, and Chen (2011); Hsu, Tsunghou and Liangfan (2011).

2. The direct influence of self-leadership on innovative behavior is shown through the path coefficient of 0.466 with $p$-value of $0.000<0.05$. This means that Self-leadership has a significant positive effect on innovative behavior. The findings of this study are in line with some of the previous research results that are by Tasan (2013); Khodaverdi (2015); Widyani, Sugianingrat, and Sarmawa (2016); Kor (2016); Park, Moon and Hyun (2014); Hosseini, Bathae and Mohammadzadeh (2014); Gomes, Curral, Caetano and Quinteiro (2015); Ziyae and Heydari (2016).

3. The direct influence of self-efficacy on knowledge sharing is shown through the path coefficient of 0.361 with $p$-value of $0.003<0.05$. This shows that self-efficacy has a significant positive effect on knowledge sharing. A number of findings in previous studies explain that knowledge sharing is influenced by self-efficacy, such as by Shaari, Rahman and Rajab (2014); and Alhady, Idris, Sawal and Azmi (2011).

4. The direct influence self-leadership to knowledge sharing is shown through the path coefficient of 0.459 with $p$-value of $0.000<0.05$. It is said that self-leadership has a significant positive effect on knowledge sharing (Masood, Shahzad and Nosheen, 2011; Bradshaw, 2015). Chebbi and Oztel (2015) in their research also prove that self-leadership influences the knowledge sharing.

5. The direct influence of knowledge sharing on innovative behavior is shown through the path coefficient of 0.307 with $p$-value of $0.002<0.05$. It is said that knowledge sharing has a significant effect on innovative behavior. The results of this study support the results of research undertaken by Lin (2007); Yu, Fang and Chieh (2013); Abdallah, Khalil and Divine (2012), in which their research concludes knowledge sharing having an effect on innovative behavior.

6. The indirect effect of self-efficacy on innovative behavior through knowledge sharing is shown through path coefficient of 0.111 with $p$-value of $0.013<0.05$. Since the direct influence of SelfEfficacy on innovative behavior is not significant, knowledge sharing acts as a full mediation of selfefficacy influencing on innovative behavior.

7. The indirect influence of self-leadership on innovative behavior through knowledge sharing is shown through the path coefficient of 0.141 with $p$-value of $0.027<0.05$. Since the direct influence of self-leadership on innovative behavior is insignificant, the role of knowledge sharing as a mediator of self-leadership influence on innovative behavior is partial.

\section{Conclusions and Implications}

Knowledge sharing for the Endek weaving employees in Klungkung Regency is affected by selfleadership and self-efficacy. The innovative behavior of the employees is directly influenced by the knowledge sharing and self-leadership. It shows that the increase of the knowledge sharing cultures among individuals will be able to improve innovative behavior. Likewise, the increase of the self-leadership of each individual will improve the behavior of innovation. However, self-efficacy has no direct effect on the innovative behavior; it means that the employees of Endek weaving companies in the Regency of Klungkung have no confidence on their ability to do the tasks or actions necessary to achieve the results without having shared the knowledge. A person with low self-efficacy considers himself essentially unable to do everything. Therefore, knowledge sharing on this research is a significant variable on the effect of selfefficacy and innovative behavior. In addition, knowledge sharing is also a partially significant variable on the influence of self-leadership towards innovative behavior.

\section{References}

Abdallah, S., Khalil, \& Divine, A. (2012). The impact of knowledge sharing on innovation capability in United Arab Emirates organizations. International Journal of Social, Behavioral, Educational, Economic, Business and Industrial Engineering, 6(12).

Alhady, S. M., Idris A. S. A., Sawal, M. Z., \& Azmi, A. A. (2011). Knowledge sharing behavior and individual factors: A relationship study in the IClass environment. International Conference on Management and Artificial Intelligence (IPED) 6, IACSIT Press, Bali, Indonesia, 137-141.

Bandura, A. (1982). Self-efficacy mechanism in human agency. American Psychologist, 37(2), 122-147. 
(1986). Social foundations of thought and action: A social cognitive theory. Englewood Cliffs, NJ: Prentice-Hall.

Begonja, M., Cicek, F., Balboni, B., \& Gerbin, A. (2016). Innovation and business performance determinants of smes in the Adriatic region that social innovation. Economic Research Ekonomska Istrazivanja, 29(1), 1136-1149.

Bradshaw, R., Chebbi, M., \& Oztel, M. (2015). Leadership and knowledge sharing. Asian Journal of Business Research, 5(1), 1-20.

Carmeli, A. (2006). Self-leadership skills and innovative behavior at work. International Journal of Manpower, 27(1), 75-90.

Carmeli, A., Weisberg, J., \& Meiter, R. (2006). Selfleadership skills and innovative behavior at work. International Journal of Manpower, 27 (1), 75-90.

Crossan, M. M. \& Apaydin, M. (2010). A multidimensional framework of organizational innovation: A systematic review of the literature. Journal of Management Studies, 47(6), 11541191.

Gomes, C., Curral, L., Caetano, A., \& Quinteiro, P. M. (2015). Better off together: A cluster analysis of self-leadership and its relationship to individual innovation in hospital nurses. Revista Psicologia, 29(1), 45-58.

Hilmi, Faiz, M., Ramayah, T., \& Mustapha, Y. (2011). Product and process innovativeness: Evidence from Malaysian smes. European Journal of Social Sciences, 16(4), 547-555.

Hoof, B. V. \& Weenen, V. (2004). Committed to sharing commitment and CMC use as antecedents of knowledge sharing. Knowledge and Process Management, 11, 13-24.

Hosseini, S. A., Bathae, S. M., \& Mohammadzadeh, S. (2014). Does self-efficacy effect on knowledge sharing intention in e-learning system? A motivational factor analysis in Open University Malaysia (OUM). Kuwait Chapter of Arabian Journal of Business and Management Review 3(11) 35-46.

Hsiao, Y. P., Brouns, F., Bruggen, J. V., \& Sloep, P. B. (2012). Effects of peer-tutor competencies on learner cognitive load and learning performance during knowledge sharing. IADIS International Conference on Cognition and Exploratory Learning in Digital Age, 265-268.

Hsiao, H. C., Chang, J. C., Tu, Y. L., \& Chen, S. C. (2011). The Impact of self-efficacy on innovative work behavior for teacher. International Journal of Social Science and Humanity, 1(1), 31-36.
Hsu, M. L. A., Tsunghou, S., \& Liangfan, H. (2011). Creative self-efficacy and innovative behavior in a service setting: optimism as a mediator. Journal of Creative Behavior, 45(4), 258-272.

Igbaria, M. \& Iivari, J. (1995). The effects of selfefficacy on computer usage omega, 23(6), 587605.

Jimenez, D. \& Sanz-Valle, R. (2011). Innovation, organizational learning, and performance. Journal of Business Research, 64(4), 408-417.

Karadag, H. (2016). The role of SMEs and entrepreneurship on economic growth in emerging economies within the post-crisis era: An analysis from Turkey. Journal on Small Business and Entrepreneurship Development, 4(1), 22-31.

Khodaverdi, Y. (2015). The study of relationship between technological innovation management, organizational atmosphere and self-leadership on innovation process, innovation performance and activeties. Indian Journal of Fundamental and Applied Life Science, 5(2), 440-448.

Kor, B. (2016). The mediating effect of self-leadership on perceived entrepreneurial orientation and innovative work behavior in the banking sector. Springer Plus, 5, 45-58.

Lin, H. F. (2007). Knowledge Sharing and firm innovation capability: An empirical study. International Journal of Manpower 28, 315-332.

Madanchian, M., Hussein, N., \& Noordin, F. (2015). The role of smes in economic development case study of Malaysia. International Journal of Economic Research in Management, 4(3), 77-84.

Manz, C. C. (1986). Self-leadership: Toward an expanded theory of self-influence processes in organization. Academy of Management Review, $11,585-600$.

Manz, C. C. \& Neck, C. P. (2004). Mastering selfleadership: Empowering yourself for personal excellence. Pearson/Prentice-Hall. Upper Saddle River, NJ.

Masood, K., Shahzad, C., \& Nosheen, R. (2011). Effects of self-leadership knowledge management and culture on creativity. European Journal of Business and Management, 3(8), 1-12.

Momeni, M., Ebrahimpour, H., \& Ajirloo, M. B. (2014). The effect of employees self-efficacy on innovative work behavior at social security organization employees in Ardabil province. Kuwait chapter Arabian Journal of Business and Management Review, 3(8), 29-32.

Nonaka, I. \& Takeuchi, H. (1995). The knowledgecreating company. New York: Oxford University Press. 
Oduntan, K. O. (2014). The role of small and medium enterprises in economic development: The Nigerian experience. International Conference Art Economic and Management, 75-80.

Ofori, D., Osei, A., Mensah, S. A., \& Affum, E. K. (2015). Innovation and knowledge sharing: A new competitive advantage in the mobile telecommunication industry in Ghana. Science Journal of Business and Management, 3(5), 157-163.

Olowodunoye, S. A. (2015). Knowledge sharing behavior: The role of self-efficacy, organizational justice and organizational tenure. European Scientific Journal, 11(17), 254-264.

Omar, I. N. \& Mahmud, N. (2014). Effect of behavioral, cognitive and physiological strategies of self leadership on innovative work behavior. Australian Journal of Basic and Applied Sciences, 8(23), 95-100.

Omri, W. (2015). Innovative behavior and venture performance of SMEs: The moderating effect of environmental dynamism. European Journal of Innovation Management, 18(2), 195-217.

Park, G. R., Moon, G. W., Hyun, S. E. (2014). An impact of self leadership on innovative behavior in sports educators and understanding of advanced research. The SIJ Transactions on Industrial, Financial \& Business Management, 2(3), 117-122.

Scumpeter, J. (1934). The theory of economics development. Cambridge, MA: Harvard University Press.

Shaari, R., Rahman, S. A. A., \& Rajab, A. (2014). Self-efficacy as a determined factor for knowledge sharing awareness. International Journal of Trade, Economics, and Finance, 5(1), 39-42.

Tasan, S. B. (2013). The influences of participative organizational climate and self-leadership on innovative behavior and the roles of job involve- ment and proactive personality: A survey in the context of smes in Izmir $2^{\text {nd }}$ International Conference on Leadership, Technology and Innovation Management. Procedia-Social and Behavioral Sciences 75, 407-419.

Van Den Hooff, V .D. B. \& De Ridder, J. A. (2004), Knowledge sharing in context: The influence of organizational commitment, communication climate and $\mathrm{cmc}$ usage on knowledge sharing. Journal of Knowledge Management, 8(6), 117130.

Widyani, D. A. A. (2016). Peran mediasi absorption capacity: pengaruh knowledge sharing terhadap inovasi pada koperasi di wilayah Denpasar Selatan. Abstrak Seminar Nasional, Inovasi Ipteks Perguruan Tinggi Untuk Meningkatkan Kesejahteraan Masyarakat, 2, 125.

Widyani, D. A. A., Sugianingrat, I. A. W., \& Sarmawa, I. W. G. (2016). Peran Entrepreneurial Orientation dalam memediasi self-leadership dan innovation behavior pada karyawan Endek weaving di Klungkung Bali. Seminar Nasional Hasil Penelitian; Prosiding Meningkatkan Mutu Penelitian dan Peringkat Perguruan Tinggi, 16.

Yonica, O. (2013). The impact of innovation in Romaniance small and medium sized enterprises on economic growth development. Journal of Knowledge Management, Economics and Information Technology, 409-423.

Yu, C., Fang, T., \& Chieh, C. (2013). Knowledge sharing, organizational climate, and innovative behavior: A cross-level analysis of effects. Social behavior and personality, 41(1), 143156.

Ziyae, B. \& Heydari, R. (2016). Investigating the effect of self-leadership on entrepreneurs' innovation in small and medium sized enterprises. International Journal of Humanities and Cultural Studies, 2(4), 1169-1182. 